Regional press sales have been steadily declining for the last 15 years, with many local titles at an all time low.

In contrast, the mass popularity of social media such as Facebook and Twitter offers charities an opportunity to deliver messages, sign people up for fundraising initiatives and become more interactively involved.

Our organisation is about to embark on a number of strategically targeted social media campaigns to raise more money and make full use of the marketing opportunities this can offer. This will include a viral campaign, centred around the open air screening of the movie 'Twilight' locally.

Methods Twilight has over 19 million Facebook followers which means that we can use well targeted advertising on Facebook as a key method to sell tickets online for the event. People click on the advert, which will be displayed on their own Facebook page, to take them through to an event page where they can buy a ticket online.

Results Desired results for a project of this nature are clear to sell all tickets and create an exciting fundraising event without the traditional hard hitting charity campaign attached. In the current economic climate, there is a sense - even if not scientific, that donor fatigue will set in, especially with the high profile campaigns that have been operational recently.

This kind of fundraising avoids 'over selling' the need to raise money for charity. Instead, it markets a hugely exciting event to a massive audience via the various social media channels available, while raising money.

Discussion / conclusion TBC

\section{P146 SOCIAL MEDIA - THE TWILIGHT YEARS OF FUNDRAISING}

Kevin Clements St Nicholas Hospice Care, Bury St Edmunds, UK

10.1136/bmjspcare-2011-000105.146

Introduction If trends in fundraising have proven anything, it's that all non-profit organisations need to be quick to adapt in order to continue reaching and inspiring large audiences to give. 